\title{
Hydrolysis of Empty Fruit Bunches of Palm Oil (Elaeis Guineensis Jacq.) by Chemical, Physical, and Enzymatic Methods for Bioethanol Production
}

\author{
N. Richana, C. Winarti, T. Hidayat, and B. Prastowo
}

\begin{abstract}
Empty fruit bunch (EFB) of palm oil has significantly produced bioethanol by sequential delignification, saccharification (chemically and physically and afterwards enzymatic hydrolysis), and fermentation process. Mixing and soaking of EFB in 1\% $\mathrm{NaOH}$ solution has reduced up to $90.3 \%$ lignin. Sequential pretreatment hydrolysis of EFB in sodium hydroxide solution and steaming in autoclave for 15 minutes, and subsequently the addition of xylanase and cellulase pH 6 and incubation for 6 days has shown the best process in which $19.34-\mathbf{2 0 . 5 6 \%}$ sugars have been released. Scanning Electron Microscope (SEM) analysis has shown clearly visible alteration before and after hydrolysis. Pretreatment heating in microwave after acid or alkaline hydrolysis significantly damaged the cell structures. Fermentation process by Saccharomyces cerevisae was done in 2 days which $540-655 \mathrm{ml}$ of $90 \%$ ethanol was resulted from pilot plant scale $3.82-4.63 \mathrm{~kg}$ EFB.
\end{abstract}

Index Terms-Bioethanol, chemicall and pysicall pretreatment, enzymatic hydrolysis, fruit bunch-palm oil.

\section{INTRODUCTION}

Recently, depletion of fossil to obtain fuel stock in the world has been occured; therefore interest in utilizing biomass as material source of renewable energy is increasing.

There are two types of biomass i.e.: i) starchy and ii) lignocellulosic. These material are usually converted into ethanol as fuel of various engines. The cost of raw material continues to be a limiting factor in the production of bioethanol (fuel alcohol) from traditional raw materials (such as invert sugars) which can be used as substrate of the yeast-based fermentation process. At the same time, there are abundant agricultural residues such as the empty fruit bunches of oil palm crop yield in palm oil industry. Processing of this waste products has two benefical effects i.e.: i) able to increase of added-value, and ii) overcome of environmental problems. Thus increases possibility to create of zero waste and clean industry of palm oil [1].

Oil palm crop has been scattered in 22 provinces in Indonesia. In 2010 oil palm area was covered 8.4 millions ha and widely increased up to 9.5 millions ha in 2012 .

Manuscript received January 15, 2014; revised March 14, 2015. This work was supported in part by Indonesian Agency for Agriculture Research and Development.

N. Richana, C. Winarti, T. Hidayat are with the Indonesian Center for Agriculture Postharvest Research and Development, Jl. Tentara Pelajar 12, Cimanggu Bogor, Indonesia (e-mail: r1ch4n4@yahoo.co.id, Christina.winarti01@gmail.com, hidayat_pasca@yahoo.com).

B. Prastowo is with the Indonesian Center for Estate Crops Research and Development, Jl Tentara Pelajar 1, Cimanggu, Bogor, Indonesia (e-mail: bprastowo@gmail.com).
Increasing of oil palm estate crop ultimately increase of EFB as waste product of oil palm industry. It is the greatest component of freshly fruit bunch of oil palm crop yield. There is $230-250 \mathrm{~kg}$ EFB in $1000 \mathrm{~kg}$ of freshly fruit bunch.

The former research result reported EFB containing 41.3-45\% cellulose, $25.3-33.8 \%$ hemicellulose, and 27.6-32.5\% lignin [2]-[4]. Significantly high of lignocellulose content of the EFB is degradable into simple compound i.e. sugar as material source of ethanol production due to fermentation process.

Pretreatment on the lignocellulose of EFB is key in order to reduces of lignin and hemicellulose before production process into bioethanol [3]-[5]. Reducing hemicellulose also increasing of pores size of biomass [6]. Hydrolysis of lignocellulose able to carried out with acid or alkaline solution and then steaming under high temperature and pressure [4], [7] and [8].

The comparative advantages of utilization lignocellulose from EFB i.e.: i) not interfere of food supply and ii) able to overcome of environmental problem in order to create zero waste and sustainable industry.

This research will develop the saccharification technique of the EFB fibres via enzymatic process to produce fermentable sugar in bioethanol production. The aim of this study i.e.: i) to improve the yield of sugars production via chemical ( $\mathrm{NaOH}$ or $\mathrm{H} 2 \mathrm{SO} 4)$ and physical (using autoclave or microwave) pretreatments of the $\mathrm{EFB}$, ii) to improve the yield of fermentable sugars production using cellulolytic and xylanolytic enzymes, and iii) to produce bioethanol from hydrolysate of EFB.

\section{MATERIALS AND METHODS}

\section{A. Raw Materials Preparation and Characterization}

Empty fruit bunch (EFB) fibres of oil palm was supplied by an palm oil industry of PTP Nusantara VIII at Malingping, Banten, West Java. Wet fibres of EFB was dried in suny days and followed in the oven $50^{\circ} \mathrm{C}$ for acceleration of drying process. Dried fibres of EFB were chop into very small size of 1.0-1.5 cm length. These fibre pieces was grind and poured into 50-80 mesh of siever. These flour like materials were resulted via sieving process were ready to use for conversion processing into the end product (bioethanol).

These flour materials of EFB were analyzed using AOAC method [9] for determination of water and fibres content. Drying was carried out in the oven $105^{\circ} \mathrm{C}$ until constant weight of fibres in order to determine of water content. Ash content determined by combustion in the blast turnace 
$500-600{ }^{\circ} \mathrm{C}$ of temperature for 6 hours. Hydrolysis in acid/ alkali solution was carried out to determine of fibres content. Lignin, hemicellulose and cellulose were determined using AOAC method [9].

\section{B. Hydrolysis of Lignocellulose}

Delignification: A hundred grams of EFB flour was mixed and then soaked in one litre of the $1 \% \mathrm{NaOCl}$ solution for 5 hours in room temperature [10]. Sample was rinsed with destilled water and then dried in the oven at $50^{\circ} \mathrm{C}$ temperature [11]. Chemical analysis was done on determination of lignin [9] hemicellulose and cellulose [12].

After delignification the estimated material composed of cellulose and hemicellulose. Further preparation of bioethanol is presented in Fig. 1. Samples were rinsed with distilled water repeatedly, and dried. The samples soak in $\mathrm{NaOH} / \mathrm{H} 2 \mathrm{SO} 4$ concentration of $8 \%$ [4]. And then it were treatment by a physical that was high pressure and temperature $\left(121^{\circ} \mathrm{C}\right.$ and $\left.1 \mathrm{~atm}\right)$ and microwave [4]-[13]. Then It washed to removed $\mathrm{NaOH} / \mathrm{H} 2 \mathrm{SO} 4$, and enzymatic hydrolysis was carried out with the addition of xylanase (50 $000 \mathrm{U} / \mathrm{g})$ and cellulase $(4000 \mathrm{U} / \mathrm{g})$ of $0.5 \mathrm{~g} / 1$ respectively [14].

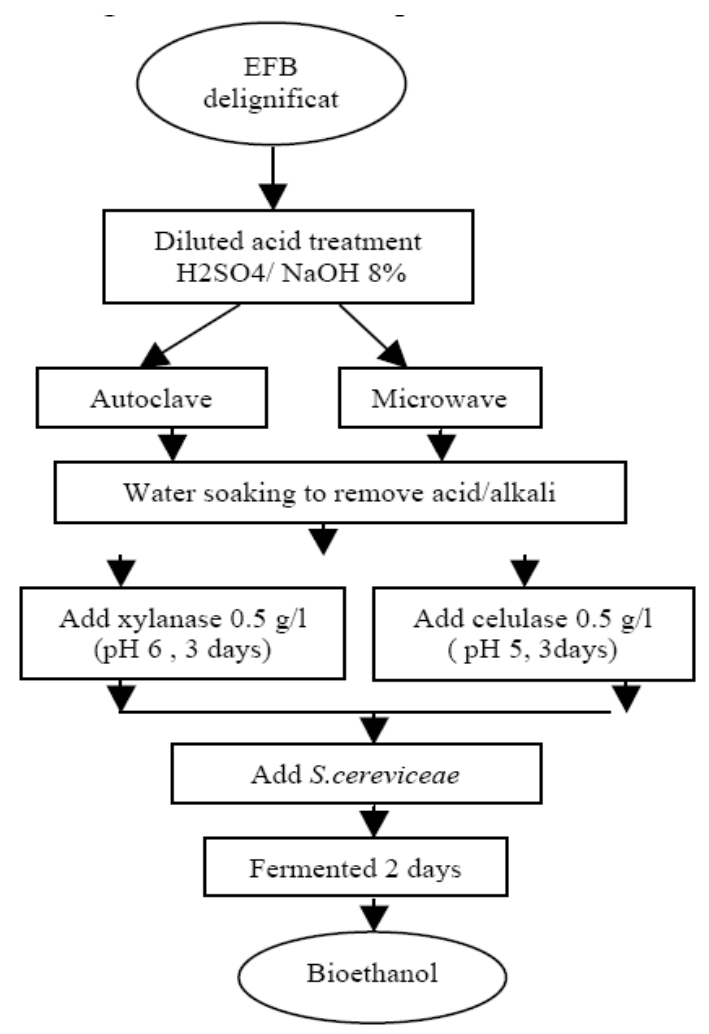

Fig. 1. Flowchart of bioethanol preparation.

Monitoring of hydrolysis of cellulose consist of determination i.e. : invert sugar by DNS method [15] and total sugars by phenol-H2SO4 method [16]. And then invert sugar results were fermented using Saccharomyces cereviseae.

Surface morphology of the cross and longitudinal views and pretreated fibres were examined by scanning electrons microscopy. Dried samples were mounted on the stub and were gold-coated prior viewing under the scanning electron microscope.

\section{RESUlt AND DisCUSSION}

\section{A. Characterization of $E F B$}

The EFB contains i.e.: 25.16, 12.78, 12.09, 10.72, and 50.03 percent of cellulose, hemicellulose, lignin, water, and fibres respectively (Table I). Recent study of [17] has reported the high content of cellulose, hemicellulose, lignin, water, and fibres i.e.: 12.78; 25.16; 12.09 and 10.72, respectively. The high content of fibres is promising to increase the yield of cellulose and xylane. Using $\mathrm{NaOH}$ solution the former research of Reference [5] reported that after delignification process the hemicellulose and lignin content were decreased up to 90 and $32 \%$ respectively. Decreasing of lignin 10-15\% from lignocellulose classify into good category.

In this study, utilization of sodium hypochlorite $(\mathrm{NaOCl})$ has reduced up to $61.29 \%$ of lignin. Reduction of lignin is faster than hemicellulose because $\mathrm{NaOCl}$ attack lignin at first time and then hemicellulose. Cellulose is the most important component of EFB. After delignification the cellulose content was relatively constant. The high cellulose content of EFB is good for material sources of bioethanol production.

TABLE I: COMPOSITION OF LIGNOCELULOSE (DB\%) FROM EMPTY FRUIT

\begin{tabular}{|l|c|c|}
\multicolumn{2}{c}{ BUNCHES OF PALM OIL } \\
\hline Composition & Before delignification & After delignification \\
\hline Moisture & 10.72 & 5.24 \\
\hline Ash & 50.03 & 43.97 \\
\hline lignin & 12.09 & 7.41 \\
\hline cellulose & 25.16 & 25.01 \\
\hline Hemicellulose & 12.78 & 11.22 \\
\hline
\end{tabular}

\section{B. Hydrolysis of EFB}

Hydrolysis after delignification of EFB was carried out in $\mathrm{H} 2 \mathrm{SO} 4$ and $\mathrm{NaOH}$ solution. This hydrolysis process reduced i.e.: lignin embedded in lignocellulose, cristalinity in cellulose, and decreased of chemicall bond between cellulose and hemicellose [18]. Reference [19] reported that hydrolysis of lignocellulose resulted mixed sugar of glucose and xylose. These two monomers are invert sugar. This hydrolysate of EFB also contains arabinose and xylobiose. Different chemical solution for treatment greatly influence on the yield of hydrolysis. Reference [16], reported that using viscous solution of sulfuric acid to hydrolyses of cellulose yielded more quantity of glucose than using thin solution. On the other using thin solution of sulfuric acid also yielded by product which inhibited of microoganism and yeast activity during fermentation process. However, using viscous solution of the sulfuric acid is expensive and dangerous on the environmental sanitation due to the water pollution.

Pretreatment with sulfuric acid or sodium hidroxyde solution only yielded of a little bit sugar. Addition of heating pretreatment in the oven or autoclave and after that simultaneously using cellulase and xylanase enzyme for fermentation resulted a lot of sugar and fermentation process run more quickly (see Table II).

Pretreatment on the lignocellulose rich materials caused: fragmentation into small pieces, reduced lignin and hemicellulose, removed crystaline structure, and increased porosity of materials [20], [21]. 
TABLE II: INVERT SUGAR (\%) RESULTED DURING HYDROLYSIS AFTER PRETREATMENT

\begin{tabular}{|l|c|c|c|}
\hline Treatment & Second day & Fourth day & Sixth day \\
\hline Acid- autoclave-enzyme & 2.93 & 8.64 & 15.41 \\
\hline Acid-microwave-enzyme & 3.08 & 8.32 & 14.07 \\
\hline Alkalin-autoclave-enzyme & 4.7 & 12.98 & 20.56 \\
\hline Alkalin- microwave-enzyme & 2.63 & 11.06 & 19.34 \\
\hline
\end{tabular}

Data were resulted 3 replication.

Removed of crystalline structure caused of the cellulose and hemicellulose is easy simultaneneously conversion into simple sugars. On the other hand, hemicellulose. The simple sugars contains arabinose, galactose, glucose, mannose, hexose, pentose and xylose.

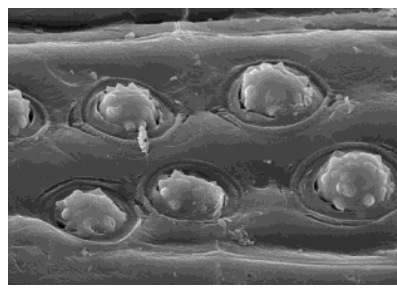

Before hidrolysis

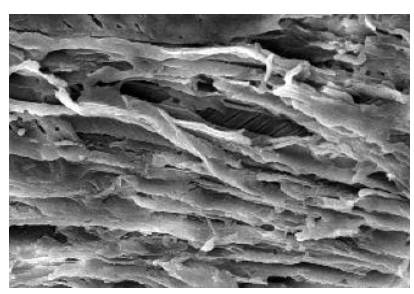

Acid-autoclave-enzyme

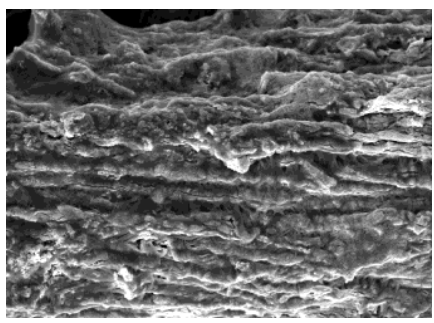

Acid-microwave-enzyme

Fig. 2. SEM images of hydrolysis EFB with acid treatment.

Alteration pattern of the surface morphology under the SEM shown cross and longitudinal views before and after hydrolysis of materials (Fig. 2 and Fig. 3). Under the SEM before and after hydrolysis in acid solution, the surface morphology of EFB was shown at Fig. 2. On the other hand using alkali solution, the surface morphology of EFB was shown at Fig. 2. Initially, under the SEM is clearly visible of the matrix structure of the cellulose and hemicellulose bond in the intact and compact cell. Similar visual structure was reported [22]. After hydrolysis in the acid or alkali solution and then heating or steaming in the oven or autoclave, the crystalline component in the centre core was start removed and. Hydrolysis of EFB in the acid solution and then heating or steaming in the oven or autoclave removed greater amount of crystalline components in the centre core than after hydrolysis in alkali solution. Based on this experiment, the acid solution able to alteration of the cell structure only in order to remove of the hemicellulose and cellulose bond. On the other hand, pretreatment by the alkali solution $(0.5 \mathrm{M}$ $\mathrm{NaOH}$ ) and steaming under $121^{\circ} \mathrm{C}, 15$ psi during 15 minutes removed of the centre core components [23]. The cell structure was damaged more seriously after heating in microwave than steaming in autoclave both in hydrolysis by acid and alkali solution. Reference [24] reported the liquid hot water pretreatment on hydrolysis of the baggase lignocellulose resulted hydrolysate containing a little bit glucose without inhibitor compound.

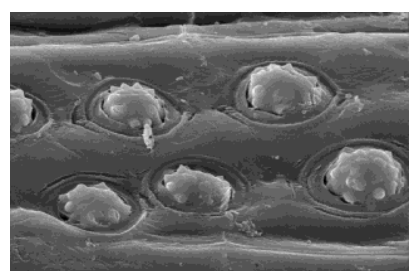

Before hidrolysis

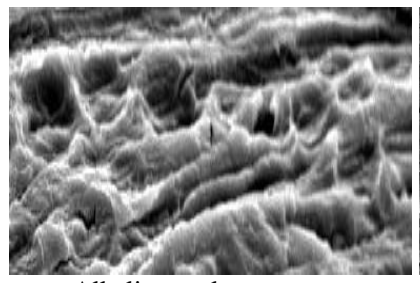

Alkali-autoclave-enzyme

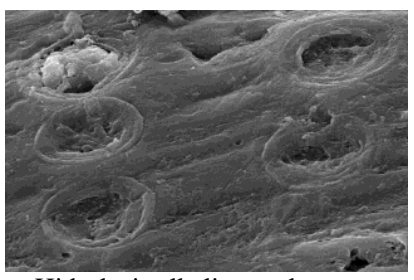

Hidrolysis alkali-autoclave

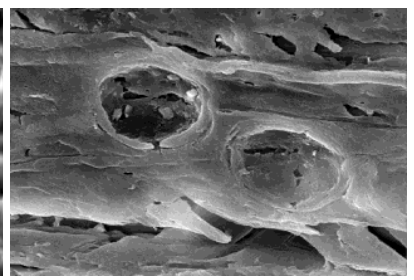

Alkali-microwave

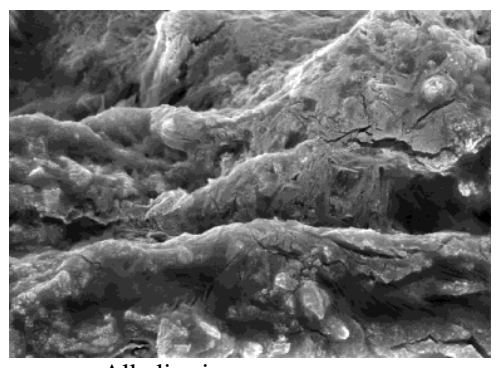

Alkali-microwave-enzyme

Fig. 3. SEM images of hydrolysis EFB with alkali treatment.

More seriously of the cell structure damaged broaden accessible area of materials on the successive enzymatic fermentation process. This condition is desirable because the saccharification and fermentation process increased yield both of glucose and ethanol respectively [25]. This experiment also shown removed of cell structure after enzymatic hydrolysis by cellulase and xylanase.

This fact illustrated that holocellulose was hydrolyzed and converted into the simple components. Fig. 2 and Fig. 3 and Table II shown correlation between the cell structure damaged and yield of the invert sugar. Hydrolysis in the acid or alkali solution and then steaming in autoclave caused more seriously damage of cell structure and increased yield of the invert sugar.

\section{Production of Ethanol from Hydrolysis of EFB}

Yield of ethanol from the fermentation process by $S$. cerevisae has correlation with the invert sugar resulted from the saccharification process (see Fig. 4). The highest yield $(262 \mathrm{ml} / \mathrm{kg}$ EFB) of $90 \%$ ethanol was resulted from pretreatment in alkali solution and then steaming in autoclave and later on addition of enzymes. On the other hand, pretreatment in acid solution and then steaming in autoclave and later on addition resulted the smallest yield of ethanol (179 $\mathrm{ml} / \mathrm{kg}$ EFB). 


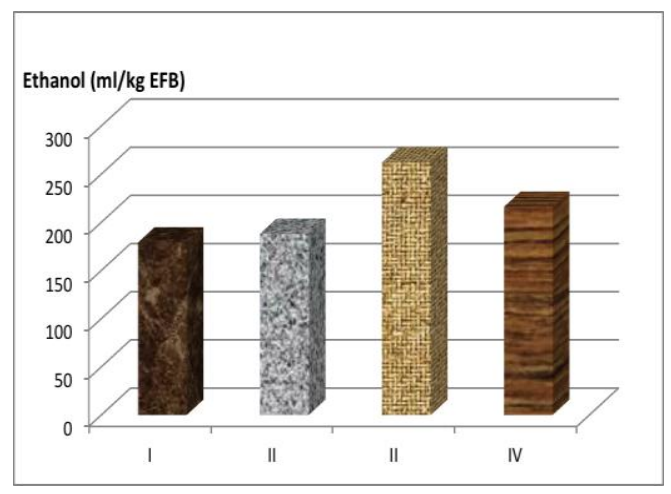

Fig. 4. The results of ethanol fermentation I: Acid-autoclave-enzyme; II. Acid-microwave-enzyme; III. Alkali-autoclave-enzyme; and IV. Alkaline-microwave-enzyme.

There are only a little bit of the another chromatogram interfere to the ethanol chromatogram (see Fig. 5). This fact indicated of successfully addition of the $S$. cerevisae in the fermentation process. On the other hand also shown hydrolyses resulted of the sugar monomers, glucose and xylose.

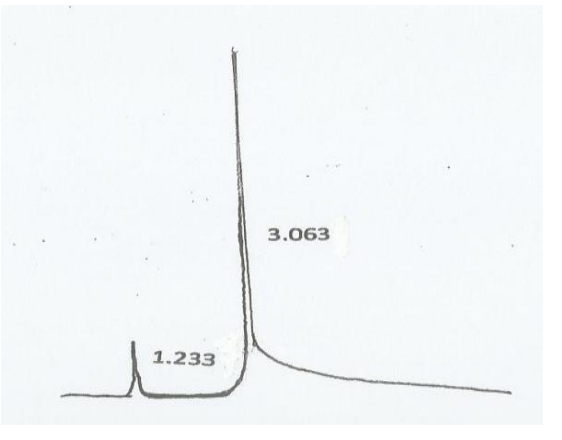

Fig. 5. Chromatogram of ethanol resulted.

In order to scale up of the similar steps and treatments in this method, $2.5 \mathrm{kgs}$ of EFB 80 mesh particle size was soaked in $50 \mathrm{ml}$ of the $4 \%$ sodium hydroxide and then steaming in the autoclave during an hour. After cooling process steaming again in autoclave for an hour. And later on the cooled materials was transferred into fermentation vessel for enzymatic hydrolysis with simultaneously addition $50 \mathrm{ml}$ of cellulase and xylanase for 3 days fermentation process. The addition 2.51 of the propagated $S$. cerevisae was carried out in the closing step and let for incubation in 3 days. The yield of this experiment was presented in Table III.

TABLE III: ETHANOL RESULTED FROM PRODUCTION OF BIOETHANOL 50 LITRE

\begin{tabular}{|l|c|c|c|}
\hline EFB/Media & $\begin{array}{c}\text { Ethanol } \\
(\mathrm{ml} / 100 \mathrm{ml})\end{array}$ & $\begin{array}{c}\text { Etanol } \\
(\mathrm{ml} / 50 \mathrm{~L})\end{array}$ & $\begin{array}{c}\mathrm{EFB}(\mathrm{kg}) / \mathrm{L} \\
\text { ethanol }\end{array}$ \\
\hline $2,5 \mathrm{~kg} / 50$ liter & 1.31 & 655 & 3.82 \\
\hline
\end{tabular}

\section{CONCLUSION}

In order to pruduce ethanol from EFB, sequential treatments consist of delignification, saccharification and fermentation in the conversion from solid state raw materials into liquid bioethanol as the end product have been studied. Mixed and soaked of $\mathrm{EFB}$ in $1 \% \mathrm{NaOCl}$ solution in delignification process reduced up to $90,3 \%$ of lignin. Pretreatment hydrolysis in $4 \% \mathrm{NaOH}$ solution of $\mathrm{EFB}$, steaming 15 minutes in autoclave, and eventually enzymatic hydrolysis by simultaneously addition of cellulase and xylanase have been carried out in order to release simple sugars. Approximately 19.34 up to $20.56 \%$ sugars was released from EFB. SEM analysis has shown clearly visible alteration of cell structure before and after consecutive hydrolysis process. In the pilot plant scale of $3.82-4.63 \mathrm{kgs}$ of EFB after 2 days fermentation process by addition of $S$. cerevisae resulted $540-655 \mathrm{ml}$ of $60 \%$ ethanol.

\section{REFERENCES}

[1] T. L. K. Yong, K. T. Lee, A. R. Mohammed, and S. Bhatia, "Potential of hydrogen from oil palm biomass a source of renewable energy worldwide," Energy Policy, vol. 35, pp. 3692-3701. 2007.

[2] R. Yunus, S. F. Salleh, N. Abdullah, and D. R. Biak, "Effect of ultrasonic pretreatment on low temperature acid hydrolysis of oil palm empty fruit bunch," Bioresour. Technol, vol. 101, pp. $9792-9796$. September 2010

[3] M. Han, Y. Kim, S. W Kim, and G. W. Choi, "High efficiency bioethanol production from OPEFB using pilot pretreatment reactor," $J$. Chemical Technolology Bioethanol, 2011.

[4] S. Kim, J. M. J. W Park, and C. H. Kim, "Sequential acid-/alkali pretreatment of oil palm empty fruit bunch fibres," Bioresource Technology, vol. 109, pp. 229-233, April 2012.

[5] D. Piarpuzan, J. A Quintero, and C. A. Cardona, "Empty fruit bunches from oil palm as a potential raw material for fuel ethanol production," Biomass Bioenginering, vol. 35, pp. 1130-1137, 2011.

[6] C. R. P. R. Bura, W. E. Mabee, A. Berlin, X. Pan, and J. N. Saddler, "Substrate pretreatment the key to effective enzyme hydrolysis of lignocellulosics?" Adv. Biochem. Eng. Biotechnol, vol. 108, pp. 69-93. 2007.

[7] D. C. Sousta, L. Chundawat, S. P. V. Balan, and B. E. Dale, "Cradle-to-grave' assessment of existing lignocellulose pretreatment technologies," Curr. Opin. Biotechnol, vol 20, pp. 339-347, 2009.

[8] M. Filzpatrick, P. Champagne, M. F. Cunningham, and R. A. Whitney, "A Biorefinery processing perspective: treatment of lignocellulosic materials for the production of value-added products," Bioresourse Technology, vol. 101, pp. 8915-8922, 2010.

[9] AOAC, "Official method analysis," The Association of Official Analytical Chemist, $16^{\text {th }}$ ed., AOAC, International, pp. 28-90, 1997.

[10] N. Richana, T. T. Irawadi, M. A. Nur, I. Sailah, and K. S. Y. Arkenan, "Ektraksi xilan dari tongkol jagung," J. Pascapanen, vol. 4, no. 1, pp. 38-43, 2007

[11] N. Richana and P. L. T. T. Irawadi, "Karakterisasi lignoselulosa dari limbah tanaman pangan dan pemanfaatannya untuk pertumbuhan bakteri RXA III-5 penghasil xilanase," J. Penel. Pert. Tan. Pangan, vol. 23 no. 3 , pp. 171-176, 2004.

[12] P. J. V. Soest, "Use of detergent in analysis of fibrous feed III," in the Handbook of Dietary Fiber, M. L. Dreher Ed., New York, USA, pp. 8-28, 1963.

[13] S. S. Hanim, M. A. M. Noor, and A. Rosma, "Effect of Hydrolysis and enzymatic treatment on oil palm (Elaeis guineensis Jacq) frond fibres for xylose and xylooligosaccharides production," Bioresource Technology, vol. 102, pp. 1234-1239, 2011.

[14] T. C. Sunarti and N. Richana, "Bioethanol production from corncob residue by two successive fermentations," Final report of Osaka Gas Foundation of International Cultural Exchange of Research Grant FY, Unpublished, 2006.

[15] G. L. Miller, "Use of dinitrosalicylic acid reagent for determination of reducing sugar," Anal. Chem., vol. 31, pp. 426-428, 1959.

[16] M. Dubois, K. A. Gilles, J. K. Hamilton, P. A. Reber, and F. Smith. "Colorimetric method for determination of sugar and related substances," Anal. Chem., vol. 28, no. 3, pp. 350-356, 1956.

[17] D. A. B. Sidik, N. Ngadis, and N. A. S. Amin, "Optimization of lignin production from empty fruit bunch via liquifaction with ionic liquid," Bioresource Technology, vol. 135, pp. 690-696, 2013.

[18] M. J. Taherzadeh and K. Karimi. "Enzyme-based hydrolysis process for ethanol production from lignocellulosic materials," J. Bioresources Technology, vol. 2, no. 4, pp. 707-738.

[19] C. S. Gong and G. T. Tsao, "Cellulose and biosynthesis regulation," Annual Report Fermentation Process, Academic Press, New York, pp. 75-89, 2010

[20] Y. Sun and J. Cheng, "Hydrolysis of lignocellusic material for ethanol production," Bioresource Technology, vol. 83, pp. 1-11, 2002. 
[21] M. A. K. M. Zahari, M. R. Zakaria, H. Arifin, M. N. Mochtar, J. Salihon, Y. Shirai, and M. A. Hasan, "Renewable sugar from oil palm frond juice as an alternative novel fermentation feedstock for value-added products," Bioresources Technol, vol. 101, pp. 566-571, 2012.

[22] G. Najafpour, A. Ideris, S Salmanpour, and M Norouzi, "Acid Hydrolysis of pretreated palm oil lignocellulosic wastes," IJE Transactions B: Applications, vol. 20, no. 2, pp. 147-155, 2007.

[23] H. Arifin, N. Abdullah, U. Kalsom, M. S. Abdullah, and N. Shirai, "Effect of physical, chemical and thermal pretreatments on the enzymatic hydrolysis of palm empty fruit bunch (OPEFB)," J. Tropical Agric. Food Science, vol. 36, pp. 259-268, 2008.

[24] S. Samsudin, M. S. U. Kalsom, H. Zainudin, S. A. Aziz, S. M. M. Kamal, Y. Shirai, and M. A. Hassan, "Effect of steam pretreatment on oil palm empty fruit bunch for the production of sugars," J. Biomass and Bioenergy, vol. 36, pp. 280-288, January 2012.

[25] A. A. Astima, "Preparation of cellulose from oil palm empty fruit bunches via ethanol digestion effect of acid and alkali catalyst," J. Oil Palm Research, vol. 14, pp. 9-14, 2002.

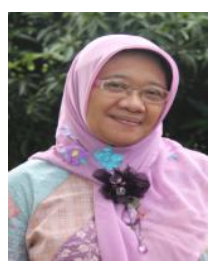

Nur Richana was born in Central Java, Indonesia on July, 25, 1954 . She has obtained a BSc degree in Gajah Mada University and her M.Sc and Ph.D degree in the year 2006 from Bogor Agriculture University. She is working as a researcher in postharvest technology, at Indonesian Agency for Agricultural Research and Development, Ministry of Agriculture as a researcher since 1983. She is also a college research profesor at Bogor Agriculture University and Gajah Mada University. She has published several research articles in the field of bioprocess engineering and postharvest technology. Her research interest include production of enzyme, fermentation and production of biofuels.

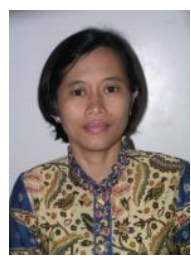

Christina Winarti was born in Jogjakarta, Indonesia on April 24, 1968. She graduated from Gadjah Mada University from Department of Post Harvest Technology in 1992 and completed her master degree from graduate school of International Development (GSID) Nagoya University, and $\mathrm{PhD}$ from Department of Agroindustrial Technology, Bogor, Agricultural University, Indonesia, in 2014. Currently, she is working as a researcher at Indonesian Agency for Agricultural Research and Development (ICAPRD), Ministry of Agriculture. She is conducting research on postharvest technology especially in processing and application of biomaterial. Her research interest is on biomaterial engineering including bio-nanotechnology and nutraceuticals.

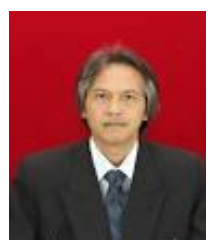

Tatang Hidayat was born on November 8, 1962 in Indonesia. He obtained a BSc degree from Padjadjaran University, Indonesia in 1988. He got his MSc from Bogor Agricultural University, Indonesia in 2005. Both of the degrees are in agricultural technology. He worked at Indonesian Agency for Agricultural Research and Development, Ministry of Agriculture as a researcher since 1990. He has published several research articles in the field of agro-processing technologies including waste. His research interests in the product development especially in the biopolymer and production of biofuels.

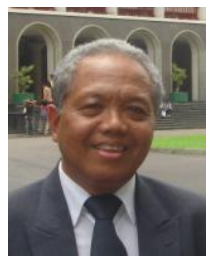

Bambang Prastowo studied agricultural engineering in Gadjah Mada University, Jogja, Indonesia, graduated in 1977 and graduated doctoral degree from Bogor Agriculture Institute Bogor, Indonesia, graduated in 1983. $\mathrm{He}$ is the director of Farm Machinery Development from 2000 to 2005 and the director of the Indonesian Center for estate crops research and development (ICERD), Ministry of Agriculture (MoA) from 2005 to 2008 . He established research installation of bioenergy and the jatropha curcas processing center and jatropha curcas seed garden and other energy's crops development center in Pakuwon, Sukabumi West Java Indonesia since 2005. Bioenergy laboratory and utilization of agriculture biomass for $2^{\text {nd }}$ generation biofuel in ICERD Bogor and Sukabumi, Indonesia (up to now). He was an invited speaker in some international workshops and conferences on farm machinery, biofuel, biomass energy development in Univ of Hohenheim Germany, South Korea, China, Tokyo University of Agric and Technology Japan, Thailand, Malaysia and Indonesia from 2004 to 2013 . He has been a research professor in 2009, a senior researcher and research professor on agricultural engineering and agriculture technology and bioenergy in Indonesian Center for Estate Crops Research and Development (ICERD) Bogor Indonesia. He is also a member of technical team of Indonesia National Standard of Bioenergy. He is a resource scientist at the Indonesian Nasional Team for the Biofuel Development, Republic of Indonesia and member of the Indonesian National Team for Biofuel Pricing, Ministry of Energy And Mineral. 